\title{
Anti-Cyclic Citrullinated Peptide and Rheumatoid Factor (Prevalence and Association) in Saudi Rheumatoid Arthritis Patients
}

\author{
Mohammad-Ayman A. Safi', PhD (UK), and \\ Dhiya T. Alhaj Houssien ${ }^{1}$, M. Med Sc, PhD (UK) \\ 'Department of Medical Microbiology and Parasitology, Faculty of Medicine \\ King Abdulaziz University, Jeddah, Saudi Arabia \\ ${ }^{2}$ Dr. Dhiya Centre for Rheumatism \& Physiotherapy and Acupuncture, Jeddah, Saudi Arabia
}

\section{Correspondence}

Dr. Mohammad-Ayman A. Safi,

Associate Professor of Immunology,

Department of Medical Microbiology and

Parasitology, Faculty of Medicine

King Abdulaziz University

P.O. Box 80205, Jeddah 21589, Saudi Arabia

e.M: aymansafi3@hotmail.com

\section{Submission: 04 Sept. 2018}

Accepted: 13 Dec. 2018

\section{Citation}

Safi MA. Houssien DT. Anti-cyclic citrullinated peptide and rheumatoid factor (prevalence and association) in Saudi rheumatoid arthritis patients. JKAU Med Sci 2018; 25 (2): 1-10. DOI: 10.4197/Med. 25.2.1

Copyright: @The Author(s), YEAR. Publisher. The Journal of King Abdualziz University - Medical Sciences is an Official Publication of "King Abdulaziz University". It is an open-access article distributed under the terms of the Creative Commons Attribution Non-Commercial License, which permit unrestricted non-commercial use, distribution, and reproduction in any medium, provided the original work is properly cited.

\begin{abstract}
To assess the prevalence and association of anti-cyclic citrullinated peptides and rheumatoid factor in Saudi rheumatoid arthritis patients. Over three years (February 2011 - February 2014). Demographic and clinical features, drugs, rheumatoid factor-positivity, and anticyclic citrullinated peptides-positivity were recorded for 205 Saudi rheumatoid arthritis patients (185 females; mean age was 45 years and mean disease duration was 5 years). Anti-cyclic citrullinated peptides and rheumatoid factor were assessed in serum. Disease activity scores for 28 joints was used. There were $36 \%$ rheumatoid factor+ve and $45 \%$ anti-cyclic citrullinated peptides+ve. $21.5 \%$ of the rheumatoid factor-ve subjects were anti-cyclic citrullinated peptides+ve. $13.3 \%$ of the rheumatoid factor positive patients were anti-cyclic citrullinated peptides-ve and $86.7 \%$ were anticyclic citrullinated peptides+ve. Significant association $(P<0.05)$ of anti-cyclic citrullinated peptides-positivity and rheumatoid factorpositivity with each other, and with gender, use of disease-modifying antirheumatic drugs, hydroxychloroquine and methotrexate. No direct impact of anti-cyclic citrullinated peptides status on the disease activity scores for 28 joints or its constituents $(P>0.5)$; nevertheless, anti-cyclic citrullinated peptides positive patients appear to represent a greater need for combination disease modifying drugs. Although anti-cyclic citrullinated peptides and rheumatoid factor were closely related, their divergence was sufficient to indicate that both should be measured in Saudi rheumatoid arthritis patients.
\end{abstract}

\section{Keywords}

Saudi Arabia; Anti-cyclic citrullinated peptides antibodies;

Rheumatoid arthritis; Rheumatoid factor; Clinical association 


\section{Introduction}

$R$ heumatoid arthritis (RA), which is a systemic autoimmune disease, affects around $1 \%$ of the general population worldwide ${ }^{[1]}$. An early intervention with RA is important for minimizing the consequences of the disease $\mathrm{e}^{[2]}$. Rheumatoid factor (RF) was the only laboratory criterion among the seven criteria that were approved (for RA diagnosis) by the "American College of Rheumatology" ("ACR"; 1987) ${ }^{[3]}$. RF had become the primary laboratory diagnostic test for $\mathrm{RA}^{[4]}$. The positivity of RF among RA patients was about $50-80 \%$, with incomplete sensitivity and specificity that limited its diagnostic value ${ }^{[5-8]}$.

More autoantibodies had been found in the sera of RA patients, that were specific but less sensitive with inconveniency for routine use from the technical point of view ${ }^{[9]}$. Recent assays have used peptides that contain citrulline but the sensitivity was low ${ }^{[10]}$. Cyclic variants of these peptides were used as antigen in the first generation of these assays and were called cyclic citrullinated peptides (CCP ${ }^{[10,11]}$. However, second generation CCP (CCP2) tests ${ }^{[12,13]}$ showed high sensitivity and specificity to $\mathrm{RA}^{[13]}$. Third-generation anti-CCP (CCP3) assays were developed that were more sensitive than those of the CCP2 assays ${ }^{[14,15]}$.

Compared with RF testing, anti-CCP testing was better for disease prediction ${ }^{[16,17]}$ and prognosis ${ }^{[18]}$, while RF was better for the response to therapy ${ }^{[19]}$. Actually, anti-CCP can be detected at an early stage of RA, even prior to the onset of clinical symptoms ${ }^{[17]}$, and considered for the early diagnosis of RA in highrisk groups, such as relatives from patients ${ }^{[20]}$. Recently (2010), anti-citrullinated protein antibodies (ACPA) testing was considered as substantial part of "The 2010 ACR-EULAR Classification Criteria for Rheumatoid Arthritis"[21].

Mostly, anti-CCP in general have been studied in European subjects ancestry ${ }^{[22]}$, with few studies having been done in some developing counties: subjects from Egypt $^{[23]}$, from Iran ${ }^{[24]}$, Thai subjects ${ }^{[25]}$, from India ${ }^{[26]}$, Black subjects from South Africans ${ }^{[27]}$, and from Syria ${ }^{[28]}$. Among Saudi subjects were evaluated the prevalence of anti-CCP, together with their relationship to disease activity, in Saudi RF-ve RA patients seen (between February 2009 and February 2011) in a private centre for rheumatology in Jeddah ${ }^{[29]}$. In the current study we assess the prevalence and association of Anti-CCP and RF in a different cohort of Saudi RA patients seen (between February 2011 and February 2014) in the same private centre.

\section{Patients and Methods}

\section{Patients}

A retrospective review of consecutive patients seen over three years (February 2011-February 2014) was undertaken for RA patients seen on the first visit to Dr. Dhiya Centre for rheumatism, acupuncture and physiotherapy in Jeddah, Saudi Arabia. All of the patients met the 1978 classification criteria of ACR for $\mathrm{RA}^{[30]}$.

\section{Assessments}

The recorded data consisted of demographic (gender, age, and nationality), clinical [disease duration/ per years, disease-modifying antirheumatic drugs (DMARDs) use and the starting date, early morning stiffness in minutes, 28 joint count for swelling (SJ) and for tenderness (TJ) and physician's global assessment (PGA) as $100 \mathrm{~mm}$ on scale] as well as laboratory data erythrocyte sedimentation rate (ESR) as $\mathrm{mm} / \mathrm{h}$, C-reactive protein, anti-CCP, RF, hemoglobin, and platelets count. The 28 joint Disease Activity Score (DAS28) was used for the assessment of the disease activity ${ }^{[31]}$, that was calculated according to SJ, TJ, PGA, and ESR. Assessment of anti-CCP was by using electrochemiluminescence (Roche Elecsys Machine), that is a CE ("European Conformity") approved as antiCCP2 and according to the manufacturer instructions the positivity starts when the concentration was $\geq 3$ $\mathrm{IU} / \mathrm{ml}$. Latex agglutination was used for assessment of immunoglobulin M RF.

\section{Prior Related Research}

Prior related studies were checked by several methods including the Saudi Digital Library, Entrez-PubMed and Advanced search - PubMed - NCBI.

\section{Statistical Analysis}

The data were analysed using Statistical Package for Social Sciences, Version 14. (SPSS Inc., Chicago, IL USA). Significant results were indicated when the $p$-value was less than 0.05 . The significant association was assessed by the chi-squared test and odds ratio with SPSS version 14. The predictive value of anti-CCP 
positivity for the various DMARDs, was analyzed using the multivariate Linear Regression Analysis (Stepwise Model); with a confidence interval 95\%.

\section{Results}

We studied 205 RA patients, of which 185 were females and 20 were males; the mean age was 45 years. All were Saudi Arabian who met the 1978 classification criteria of ACR for RA. Their features (the demographic, the clinical and the laboratorian) are summarized in Table 1.

Most of the patients (200/205, 98\%) received DMARDs. These comprised hydroxychloroquine sulphate in $146(71 \%)$ patients with $80(39 \%)$ receiving it as a monotherapy, sulfasalazine in 29 (14\%) with 8 (4\%) as monotherapy, methotrexate in $85(41 \%)$ with $21(10 \%)$ as monotherapy, leflunomide in $15(7 \%)$ always as in combination and Adalimumab in $3(2 \%)$ always in combination. Glucocorticoids (prednisolone) were received by $52(25 \%)$ patients. Combination DMARDs were used in 90 (44\%) patients.

Overall 75/205 (37\%) patients were RF positive and 93/205 (45\%) were anti-CCP positive (Table 2). There were strong associations between rheumatoid factor positivity and anti-CCP positivity in all patients and early and established RA (Table 2). 65/75 (87\%) patients who were positive for rheumatoid factor were

Table 1. Patients' demographic and clinical characteristics.

\begin{tabular}{|l|l|l|}
\hline \multirow{4}{*}{ Category } & \multicolumn{1}{|c|}{ Variable } & \multicolumn{1}{|c|}{$\begin{array}{c}\text { Mean (Standard Deviation) } \\
\text { or Number (\%) }\end{array}$} \\
\hline \multirow{5}{*}{ Demographic } & Age & 45 years (SD13) \\
\cline { 2 - 3 } & Sex (Female/Male) & $185 / 20(90.25 \% / 9.75 \%)$ \\
\cline { 2 - 3 } & Disease Duration & 4.7 years (SD 6.3) \\
\cline { 2 - 3 } & Disease Duration $\leq 1$ year. & $80(39.02 \%)$ \\
\hline \multirow{5}{*}{ Disease Activity } & Tender Joint Count & $14.2($ SD 5.2) \\
\cline { 2 - 3 } & Swollen Joint Count & $2.8($ SD 1.6) \\
\cline { 2 - 3 } & Patient Global Assessment & $64 \mathrm{~mm}$ (SD 9) \\
\cline { 2 - 3 } & Erythrocyte Sedimentation Rate & $39 \mathrm{~mm} / \mathrm{h}($ SD 24) \\
\cline { 2 - 3 } & 28-joint Disease Activity Score & $5.8($ SD 0.8) \\
\hline \multirow{5}{*}{ Treatment } & Disease-Modifying Antirheumatic Drugs & $200(97.56 \%)$ \\
\cline { 2 - 3 } & Hydroxychloroquine Sulphate & $146(71.22 \%)$ \\
\cline { 2 - 3 } & Sulfasalazine & $29(14.14 \%)$ \\
\cline { 2 - 3 } & Methotrexate & $85(41.46 \%)$ \\
\cline { 2 - 3 } & Leflunomide & $15(7.32 \%)$ \\
\cline { 2 - 3 } & Adalimumab & $3(1.45 \%)$ \\
\cline { 2 - 3 } & Combination DMARDs & $90(43.90 \%)$ \\
\cline { 2 - 3 } & Glucocorticoids (Prednisolone) & $52(25.36 \%)$ \\
\hline
\end{tabular}

DMARDs: Disease-modifying antirheumatic drugs

Table 2. Anti-cyclic citrullinated peptides positivity versus rheumatoid factor positivity.

\begin{tabular}{|c|c|c|c|c|c|c|}
\hline \multirow{2}{*}{\multicolumn{3}{|c|}{ Group }} & \multicolumn{2}{|c|}{ Rheumatoid Factor } & \multirow{2}{*}{ Total } & \multirow{2}{*}{ Significance } \\
\hline & & & Negative & Positive & & \\
\hline \multirow{3}{*}{ All } & \multirow{2}{*}{ Anti-CCP } & Negative & $102(78.46 \%)$ & $10(13.33 \%)$ & 112 (54.63\%) & \multirow{3}{*}{$\begin{array}{l}\text { Chi-Squared } 82 \\
D F=1 ; P<0.001\end{array}$} \\
\hline & & Positive & $28(21.54 \%)$ & $65(86.67 \%)$ & $93(45.37 \%)$ & \\
\hline & Total & & 130 & 75 & 205 & \\
\hline \multirow{3}{*}{ Early } & \multirow{2}{*}{ Anti-CCP } & Negative & $43(87.75 \%)$ & $6(18.75 \%)$ & $49(60.50 \%)$ & \multirow{3}{*}{$\begin{array}{l}\text { Chi-Squared 38; } \\
D F=1 ; P<0.001\end{array}$} \\
\hline & & Positive & $6(12.25 \%)$ & $26(81.25 \%)$ & $32(39.50 \%)$ & \\
\hline & Total & & 49 & 32 & 81 & \\
\hline \multirow{3}{*}{ Established } & \multirow{2}{*}{ Anti-CCP } & Negative & $59(72.84 \%)$ & $4(9.30 \%)$ & $63(50.80 \%)$ & \multirow{3}{*}{$\begin{array}{l}\text { Chi-Squared 45; } \\
D F=1 ; P<0.001\end{array}$} \\
\hline & & Positive & $22(27.16 \%)$ & $39(90.70 \%)$ & $61(49.20 \%)$ & \\
\hline & Total & & 81 & 43 & 124 & \\
\hline
\end{tabular}

Anti-CCP: Anti-cyclic citrullinated peptides; Early RA: When the disease duration was equal or less than one year; Established RA: When the disease duration was more than one year DF:Degrees of freedom 
also positive for anti-CCP. However, 28/130 (22\%) of patients negative for rheumatoid factor were positive for anti-CCP.

The prevalence of the anti-CCP was 93/205 (45.4) in total cohort; $28 / 130$ (21.5\%) in RF-ve patients (Table 2). $14 / 20(70 \%)$ in males and $79 / 185(42.7 \%)$ in females (Table 3).

Men were more likely to be positive for anti-CCP and rheumatoid factor than women (Tables 3 and 4). Patients who were positive for anti-CCP and rheumatoid factor were also more likely to be receiving treatment with methotrexate and combination DMARDs (Tables 3 and 4). The Linear Regression Analysis (Stepwise) of different DMARDs related to the positivity of antiCCP showed significant relationship with receiving methotrexate $(p<0.001)$, but not with other DMARDs, though R2 was $15 \%$ indicating this association was relatively weak (Table 5).

Comparing the frequencies of positive results for anti-CCP and rheumatoid factor (Table 6) showed this was most marked in patients aged 30-39, though there

Table 3. Associations of anti-cyclic citrullinated peptides positivity.

\begin{tabular}{|c|c|c|c|c|c|}
\hline \multirow{2}{*}{\multicolumn{2}{|c|}{ Variable }} & \multicolumn{2}{|c|}{ Anti-CCP } & \multirow{2}{*}{ Total } & \multirow{2}{*}{ Significance } \\
\hline & & \multirow{2}{*}{$\begin{array}{c}\text { Positive } \\
79\end{array}$} & \multirow{2}{*}{$\begin{array}{c}\text { Negative } \\
106\end{array}$} & & \\
\hline \multirow{2}{*}{ Gender } & Female & & & 185 & \multirow{2}{*}{ Chi-Squared 5.4; DF=1;P=0.02 } \\
\hline & Male & 14 & 6 & 20 & \\
\hline \multirow{2}{*}{ Hydroxychloroquine } & Receiving & 54 & 92 & 146 & \multirow{2}{*}{ Chi-Squared 14.4; $D F=1 ; P<0.001$} \\
\hline & Not-Receiving & 39 & 20 & 59 & \\
\hline \multirow{2}{*}{ Methotrexate } & Receiving & 58 & 27 & 85 & \multirow{2}{*}{ Chi-Squared 30.6; $D F=1 ; P<0.001$} \\
\hline & Not-Receiving & 35 & 85 & 120 & \\
\hline \multirow{2}{*}{ Combination DMARDs } & Receiving & 54 & 36 & 90 & \multirow{2}{*}{ Chi-Squared 13.9; $D F=1 ; P<0.001$} \\
\hline & Not-Receiving & 39 & 76 & 115 & \\
\hline
\end{tabular}

Anti-CCP: Anti-cyclic citrullinated peptides positivity; DF: Degrees of freedom; DMARDs: Disease-modifying antirheumatic drugs

Table 4. Associations of rheumatoid factor positivity.

\begin{tabular}{|c|c|c|c|c|c|}
\hline \multirow{2}{*}{\multicolumn{2}{|c|}{ Variable }} & \multicolumn{2}{|c|}{ Rheumatoid Factor } & \multirow{2}{*}{ Total } & \multirow{2}{*}{ Significance } \\
\hline & & Positive & Negative & & \\
\hline \multirow{2}{*}{ Gender } & Female & 61 & 124 & 185 & \multirow{2}{*}{ Chi-Squared 10.7; DF=1; $P=0.02$} \\
\hline & Male & 14 & 6 & 20 & \\
\hline \multirow{2}{*}{ Hydroxychloroquine } & Receiving & 42 & 104 & 146 & \multirow{2}{*}{ Chi-Squared 13.4; DF=1; $P<0.001$} \\
\hline & Not-Receiving & 33 & 26 & 59 & \\
\hline \multirow{2}{*}{ Methotrexate } & Receiving & 47 & 38 & 85 & \multirow{2}{*}{ Chi-Squared 22; DF=1; $P<0.001$} \\
\hline & Not-Receiving & 28 & 92 & 120 & \\
\hline \multirow{2}{*}{ Combination DMARDs } & Receiving & 42 & 48 & 90 & \multirow{2}{*}{ Chi-Squared 7; DF=1; P<0.01 } \\
\hline & Not-Receiving & 33 & 82 & 115 & \\
\hline
\end{tabular}

DMARDs: Disease-modifying antirheumatic drugs; DF: Degrees of freedom

Table 5. Linear regression analysis (stepwise) of disease-modifying antirheumatic drugs related to anti-cyclic citrullinated peptides positivity.

\begin{tabular}{|l|c|c|c|}
\hline \multirow{2}{*}{ Model } & \multicolumn{2}{|c|}{ Unstandardized Coefficients } & \multirow{2}{*}{ Significance } \\
\cline { 2 - 3 } & $B$ & Std. Error & 0.00 \\
\hline Methotrexate & 0.39 & 0.065 & \\
\hline
\end{tabular}

Dependent variable: anti-cyclic citrullinated peptides positivity

$R^{2}=15 \%$

Excluded variables: Hydroxychloroquine sulphate (Plaque), Sulfasalazine,

Glucocorticoids(prednisolone), Leflunomide (Arava), Adalimumab (HUMIRA) 
Table 6. Age groups, anti-cyclic citrullinated peptides positivity and rheumatoid factor positivity.

\begin{tabular}{|c|c|c|c|}
\hline Age Group & Anti-CCP Positive & Rheumatoid Factor Positive & Total \\
\hline $20-29$ & $10(40.00 \%)$ & $10(40.00 \%)$ & 25 \\
\hline $30-39$ & $34(61.82 \%)$ & $26(47.27 \%)$ & 55 \\
\hline $40-49$ & $21(36.85 \%)$ & $17(39.82 \%)$ & 57 \\
\hline $50-59$ & $16(41.02 \%)$ & $11(28.20 \%)$ & 39 \\
\hline $60-69$ & $7(43.75 \%)$ & $4(25.00 \%)$ & 16 \\
\hline$\geq 70$ & $5(38.46 \%)$ & $7(53.85 \%)$ & 13 \\
\hline
\end{tabular}

Anti-CCP: Anti-cyclic citrullinated peptides

Table 7. The 28 joint Disease Activity Score groups, anti-cyclic citrullinated peptides, and rheumatoid factor positivity.

\begin{tabular}{|l|l|c|c|c|}
\hline \multicolumn{2}{|c|}{} & DAS28 $\mathbf{5 . 1}$ & DAS28 > 5.1 & Total \\
\hline \multirow{2}{*}{ Anti-CCP } & Negative & $15(13.40 \%)$ & $97(86.60 \%)$ & 112 \\
\cline { 2 - 5 } & Positive & $12(12.90 \%)$ & $81(87.10 \%)$ & 93 \\
\hline \multirow{2}{*}{ Rheumatoid Factor } & Negative & $16(12.30 \%)$ & $114(87.70 \%)$ & 130 \\
\cline { 2 - 5 } & Positive & $11(14.66 \%)$ & $64(85.34 \%)$ & 75 \\
\hline Total & & $27(13.17 \%)$ & $178(86.83 \%)$ & 205 \\
\hline
\end{tabular}

Anti-CCP: Anti-cyclic citrullinated peptides; DAS28: 28 Joint Disease Activity Score

was also a minor increase in very elderly patients with rheumatoid factor positivity.

Finally, there was no relationship between positive findings with anti-CCP and rheumatoid factor (Table 7). $27 / 205$ patients had moderate or low DAS28 scores and 178/205 had high DAS28 scores. The frequencies of positive and negative anti-CCP and rheumatoid factor measures were similar in both groups.

\section{Discussion}

We studied 205 Saudi RA patients on their first visit to a specialist centre. All patients met the ACR classification criteria for RA. The prevalence of anti-CCP antibodies in this cohort was $45 \%$ including $22 \%$ who were rheumatoid factor negative. A similar prevalence (22\%) of anti-CCP in rheumatoid factor negative patients has been reported in Japanese patients by Matsui and coworkers $^{[32]}$. A lower prevalence (20\%) was reported for Thai rheumatoid factor negative subjects ${ }^{[25]}$. However, prevalences of $30 \%-43 \%$ have been seen in other groups of rheumatoid factor negative patients from Saudi Arabia and other populations. Safi et al. ${ }^{[29]}$, in Saudi Arabia, reported a prevalence of $30.5 \%$; this difference could be attributed to 1- the higher male percentage (double; $18 \%$ compared to $9.8 \%$ in the present study) accompanied with low anti-CCP antibodies in males (half; $38 \%$ compared to $70 \%$ in the present study) 2- and/or to the presence of higher proportion of comorbid diseases in the present study (41\% compared with $25 \%$ in the previous study) which was found to decrease the prevalence of anti-CCP positivity ${ }^{[29]}$ Additionally, among RF-ve RA subjects from Greece and from Germany the reported prevalence of antiCCP antibodies was $34.9 \%{ }^{[33]}$ and $34.5 \%{ }^{[34]}$, respectively. The authors, accordingly, suggested its usefulness for the RF-ve subjects with suspected RA. In black subjects from South Africa with early RA, the report prevalence of anti-CCP antibodies was $36.4 \%$ among 22 patients of RF-ve $\mathrm{RA}^{[27]}$. Prevalence of $40 \%$ anti-CCP-positivity among RF-ve patients was reported from Finland by Sihvonen et al. ${ }^{[35]}$, and from Swedin by Kastbom et al. ${ }^{[36]}$, and $43.2 \%$ was reported by Kroot et al. ${ }^{[37]}$ in Swedish RFve patients. And finally, positive anti-CCP was reported in $65.3 \%$ of Iranian seronegative RA patients ${ }^{[38]}$. However the low CCP antibodies in RF-ve patients (in this study $=22 \%$ ) could be attributed to the low number of smokers among the RF-ve patients (24\%), as smoking is a known risk factor for CCP antibodies ${ }^{[39-41]}$.

The disease activity DAS28 (5.8) in these cohorts was similar to our previous report ${ }^{[29]}$ (5.7) and fits within the ranges (3.1-6.0) in patients from 25 other communities ${ }^{[42]}$. The patients in these cohorts $[178 / 205(86.8 \%)]$ that had high DAS28 scores (> 5.1), was slightly higher than that Safi et al. ${ }^{[29]}$ previously reported $[80 \% ; 160 / 200)]$ yet both studies revealed no significant differences $(P>0.10)$ between +ve and -ve anti-CCP for the disease activity as estimated by DAS28, 
indicating that anti-CCP antibodies have limited value in predicting disease activity. This is compatible with Vanichapuntu and co-workers ${ }^{[25]}$, Abdel-Nasser et al. ${ }^{[23]}$ who found no correlation of anti-CCP antibodies with DAS 28 and Serdaroğlu et al. ${ }^{[43]}$ who reported no correlation between anti-CCP antibody and the serological markers of disease activity (ESR, DAS28, (RP).

In Egypt, although Abdel-Nasser et al. ${ }^{[23]}$ reported no significant correlations of anti-CCP titre with parameters of disease activity, they found correlations between anti-CCP titre and disease severity [rheumatoid nodules, rheumatoid factor (RF), and radiological damage] and HAQ-DI $(P<0.05)$. Other investigators found anti-CCP antibodies to be predictors of a severe disease course in RA, as judged by radiological joint outcome $^{[37,44]}$ or by swollen joint count and raised, 36 CRP[33].

Early RA (dd $\leq 1$ year) was found in 81 (39.5\%) patients, which was slightly higher than our previous finding ${ }^{[29]}(63 / 200 ; 31.5 \%)$. Among the 81 patients with early RA ( $d d \leq 1$ year) 32/81 (39.5\%) had positive antiCCP antibodies which is comparable with what was previously reported 29 (22/63; 35\%) and confirming that anti-CCP antibodies test can be considered as a precious predictor of the disease in the early RA when RF is still not detectable. In this respect, we are in concordance with Kastbom et al. ${ }^{[36]}$ who concluded that anti-CCP positivity is a valuable disease predictor in Swedish early RA patients ( $d d \leq 1$ year).

Associations of anti-CCP positivity and RF positivity indicated that patients who were positive for anti-CCP and rheumatoid factor were more likely to be receiving treatment with combination DMARDs and methotrexate $(P<0.001)$. This is in concordance with our previous report ${ }^{[29]}$ of significant correlation $(p \leq 0.01)$ between anti-CCP and methotrexate and prednisolone, but not the other used DMARDs.

The current baseline cross-sectional study, assessed neither the sensitivity nor the specificity of anti-CCP antibodies. Such assessment in RA in Saudi population can be a plan for a future study, using a non-RA control group and a ROC curve analysis,

Sex ratio (F:M) for RA patients had been consistently found to be around $3: 1^{[45]}$. However, according to the literature review of Almoallim and Alharbi ${ }^{[46]}$, the only study for the rate of RA in SA was published in $1998^{[47]}$ that involved a single Saudi region (Al-Qassim region), small sample size, and simple methodology. They reported a F:M ratio of 1.6:1 (4:1 for the age group of 3039 years). The cohort of our study had nine times more females than males (9:1), representing the number of patients seen in the centre during the assigned period of this retrospective study (2/2011-2/2014), and does not address the epidemiological sex differences for the Saudi RA patients. Similarly, 9:1 male-to-female ratio was reported in the study group of a recent study about the association of HLA-DRB1 with anti-CCP in Saudi RA patients ${ }^{[48]}$. However, examination of sex differences in epidemiological characteristics within a large number of RA patients should be considered for a future plan.

\section{Conclusion and Recommendations}

Although anti-CCP and RF were closely related, the divergence between them is sufficient to indicate that both should be measured in Saudi RA patients. Although anti-CCP antibodies are unrelated to immediate levels of disease activity, anti-CCP positive patients appear to represent a different clinical phenotype with a greater need for combination disease modifying drugs. More studies are needed in Saudi Arabia for the assessment of the test sensitivity and the test specificity of the antiCCP assay in Saudi Arabian population. Further studies should be performed for the rate of RA in SA together with the sex ratio (F:M) for RA patients in Saudi Arabia and for the correlation between smoking and anti-CCP.

\section{Acknowledgment}

We express our appreciation and gratitude to Dr. David L. Scott from King's College London, UK for revising the manuscript and for his valuable advice with editing of the manuscript.

\section{Ethical Approval}

As long as the collected data were part of a retrospective review, thus informed consent was not obtained; however, a written ethical approval was obtained before commencing the study.

\section{Disclosures}

Both authors have read and approved this manuscript. The current study was not funded or supported by any drug company. This paper is unique and is not under consideration by any other publication and has not been published elsewhere. 


\section{Conflicts of Interest}

\section{The authors declare that they have no conflicts of} interest.

\section{Rerefences}

[1] Firestein GS. Etiology and pathogenesis of rheumatoid arthritis. In: Textbook of Rheumatology. Kelley WN, Harris ED Jr, Ruddy S, Sledge CB (ed). $5^{\text {th }}$ ed. WB Saunders, 1997. 851897.

[2] Zendman AJ, van Venrooij WJ, Pruijn GJ. Use and significance of anti-CCP autoantibodies in rheumatoid arthritis. Rheumatology (Oxford) 2006; 45(1): 20-25.

[3] Renaudineau Y, Jamin C, Saraux A, Youinou P. Rheumatoid factor on a daily basis. Autoimmunity 2005; 38(1): 11-16.

[4] Sullivan E. Rheumatoid arthritis: test for anti-CCP antibodies joining RF test as key diagnostic tools. Lab Med 2006; 37(1): 179. Accessed February 17, 2017. <https://www. researchgate.net/publication/246757850_Rheumatoid_ Arthritis_Test_for_Anti-CCP_Antibodies_Joining_RF_Test_ as_Key_Diagnostic_Tools>.

[5] Smolen JS. Autoantibodies in rheumatoid arthritis. In: Manual of Biological Markers of Disease. van Venrooij WJ, Maini RN, ed. Dordrecht (The Netherlands): Kluwer Acad Pub, 1996. C1.1/1-18

[6] van Schaardenburg D, Lagaay A, Otten HG, Breedveld FC. The relation between class-specific serum rheumatoid factors and age in the general population. $\mathrm{Br} J$ Rheumatol 1993; 32(7): 546-549.

[7] Aho K, Palosuo T, Kurki P. Marker antibodies of rheumatoid arthritis: diagnostic and pathogenetic implications. Semin Arthritis Rheum 1994; 23(6): 379-387.

[8] Visser H, Gelinck LB, Kampfraath AH, Breedveld FC, Hazes $J M$. Diagnostic and prognostic characteristics of the enzyme linked immunosorbent rheumatoid factor assay in rheumatoid arthritis. Ann Rheum Dis 1996; 55(3): 157-161.

[9] Lee DM, Schur PH. Clinical utility of the anti-CCP assay in patients with rheumatic diseases. Ann Rheum Dis 2003; 62(9): 870-874.

[10] Schellekens GA, de Jong BA, van den Hoogen FH, van de Putte LB, van Venrooij WJ. Citrulline is an essential constituent of antigenic determinants recognized by rheumatoid arthritis-specific autoantibodies. J Clin Invest 1998; 101(1): 273-281.

[11] Schellekens GA, Visser H, de Jong BA, van den Hoogen FH, Hazes JM, Breedveld FC, van Venrooij WJ. The diagnostic properties of rheumatoid arthritis antibodies recognizing a cyclic citrullinated peptide. Arthritis Rheum 2000; 43(1): 155-163.

[12] Koivula MK. Autoantibodies binding citrullinated type and II collagens in rheumatoid arthritis. Acta Universitatis Ouluensis 2006; D 881: 1-95.
[13] Pruijn GM, Vossenaar ER, Drijfhout JW, van Venrooij WJ, Zendman A. Anti-CCP antibody detection facilitates early diagnosis and prognosis of rheumatoid arthritis. Current Rheumatology Reviews 2005; 1(1): 1-7.

[14] Santiago M, Baron M, Miyachi K, Fritzler MJ, Abu-Hakima M, Leclercq S, Bell M, Hudson M, Mathieu JP, Taillefer S, Jones N, Docherty P, Khraishi M, Markland J, Pope J, Robinson $D$, Smith $D$, Sutton E. A comparison of the frequency of antibodies to cyclic citrullinated peptides using a third generation anti-CCP assay (CCP3) in systemic sclerosis, primary biliary cirrhosis and rheumatoid arthritis. Clin Rheumatol 2008; 27(1): 77-83.

[15] Correia ML, Carvalho S, Fortuna J, Pereira MH. Comparison of three anti-CCP antibody tests and rheumatoid factor in RA and control patients. Clin Rev Allergy Immunol 2008; 34(1): 21-25.

[16] Nielen MM, van Schaardenburg D, Reesink HW, van de Stadt RJ, van der Horst-Bruinsma IE, de Koning MH, Habibuw MR, Vandenbroucke JP, Dijkmans BA. Specific autoantibodies precede the symptoms of rheumatoid arthritis: a study of serial measurements in blood donors. Arthritis Rheum 2004; 50(2): 380-386.

[17] Rantapää-Dahlqvist S, de Jong BA, Berglin E, Hallmans G, Wadell G, Stenlund $H$, Sundin $U$, van Venrooij WJ. Antibodies against cyclic citrullinated peptide and IgA rheumatoid factor predict the development of rheumatoid arthritis. Arthritis Rheum 2003; 48(10): 2741-2749.

[18] Meyer O, Labarre C, Dougados M, Goupille P, Cantagrel A, Dubois A, Nicaise-Roland P, Sibilia J, Combe B. Anticitrullinated protein/peptide antibody assays in early rheumatoid arthritis for predicting five-year radiographie damage. Ann Rheum Dis 2003; 62(2): 120-126.

[19] De Rycke L, Verhelst X, Kruithof E, Van den Bosch F, Hoffman IE, Veys EM, De Keyser F. Rheumatoid factor, but not anticyclic citrullinated peptide antibodies, is modulated by infliximab treatment in rheumatoid arthritis. Ann Rheum Dis 2005; 64(2): 299-302.

[20] Goeldner I, Skare TL, de Messias Reason IT, Nisihara RM, Silva MB, Utiyama SR. Anti-cyclic citrullinated peptide antibodies and rheumatoid factor in rheumatoid arthritis patients and relatives from Brazil.." Rheumatology (Oxford) 2010; 49(8): 1590-1593.

[21] Aletaha D, Neogi T, Silman AJ, Funovits J, Felson DT, Bingham CO 3rd, Birnbaum NS, Burmester GR, Bykerk VP, Cohen MD, Combe B, Costenbader KH, Dougados M, Emery P, Ferraccioli G, Hazes JM, Hobbs K, Huizinga TW, Kavanaugh A, Kay J, Kvien TK, Laing T, Mease P, Ménard HA, Moreland LW, Naden RL, Pincus T, Smolen JS, StanislawskaBiernat E, Symmons D, Tak PP, Upchurch KS, Vencovsky J, Wolfe F, Hawker G. 2010 rheumatoid arthritis classification criteria: an American College of Rheumatology/European League Against Rheumatism Collaborative Initiative. Ann Rheum Dis 2010; 69(9): 1580-1588. 
[22] Nishimura K, Sugiyama D, Kogata Y, Tsuji G, Nakazawa T, Kawano S, Saigo K, Morinobu A, Koshiba M, Kuntz KM, Kamae I, Kumagai S. Meta-analysis: diagnostic accuracy of anticyclic citrullinated peptide antibody and rheumatoid factor for rheumatoid arthritis. Ann Intern Med 2007; 146(11): 797-808.

[23] Abdel-Nasser AM, Mahmoud MH, El Mansoury TM, Osman AM. Anti-CCP2 is an adjunct to, not a surrogate for, rheumatoid factor in the diagnosis of rheumatoid arthritis: diagnostic utility of anti-CCP2 antibodies in Egyptian patients with rheumatoid arthritis. Scand J Rheumatol 2008; 37(5): 329-336.

[24] Aflaky E, Shenavandeh S, Ashraf MJ. A comparison of performance of anti-cyclic citrullinated peptide 2 and citrullinated protein antibodies in the diagnosis of rheumatoid arthritis in Iranian patients. Rheumatol Int 2010; 30(4): 461-466.

[25] Vanichapuntu M, Phuekfon P, Suwannalai P, Verasertniyom O, Nantiruj K, Janwityanujit S. Are anti-citrulline autoantibodies better serum markers for rheumatoid arthritis than rheumatoid factor in Thai population? Rheumatol Int 2010; 30(6): 755-759.

[26] Gupta R, Thabah MM, Aneja R, Kumar A, Varghese T, Chandrasenan PJ. Usefulness of anti-CCP antibodies in rheumatic diseases in Indian patients. Indian J Med Sci 2009; 63(3): 92-100.

[27] Hodkinson B, Meyer PW, Musenge E, Ally MM, Wadee AA, Anderson R, Tikly M. The diagnostic utility of the anti-CCP antibody test is no better than rheumatoid factor in South Africans with early rheumatoid arthritis. Clin Rheumatol 2010; 29(6): 615-618.

[28] Awwad HM, Aboukhamis I. Diagnostic performances of anti-cyclic citrullinated peptide antibodies type IgM, IgA and $\operatorname{lgG}$ in Syrian patients with rheumatoid arthritis. Clin Lab 2010; 56(3-4): 95-102.

[29] Safi MA A, Alhaj Houssien D Scott DL. Disease activity and anti-cyclic citrullinated peptide (Anti-CCP) antibody in Saudi RF-negative rheumatoid arthritis patients. JKAU Med Sci 2012; 19(3): 3-20.

[30] Arnett FC, Edworthy SM, Bloch DA, McShane DJ, Fries JF, Cooper NS, Healey LA, Kaplan SR, Liang MH, Luthra HS, Medsger Jr TA, Mitchel DM, Neustadt DH, Pinals RS, Schaller JG, Sharp JT, Wilder RL, Hunder GG. The American Rheumatism Association 1987 revised criteria for the classification of rheumatoid arthritis. Arthritis Rheum 1988; 31(3): 315-324.

[31] Prevoo ML, van't Hof MA, Kuper HH, van Leeuwen MA, van de Putte LB, van Riel PL. Modified disease activity scores that include twenty-eight-joint counts. Development and validation in a prospective longitudinal study of patients with rheumatoid arthritis. Arthritis Rheum 1995; 38(1): 44-48.

[32] Matsui T, Shimada K, Ozawa N, Hayakawa H, Hagiwara F, Nakayama H, Sugii S, Ozawa Y, Tohma S. Diagnostic utility of anti-cyclic citrullinated peptide antibodies for very early rheumatoid arthritis. J Rheumatol 2006; 33 (12): 2390-2397.

[33] Alexiou I, Germenis A, Ziogas A, Theodoridou K, Sakkas LI. Diagnostic value of anti-cyclic citrullinated peptide antibodies in Greek patients with rheumatoid arthritis. BMC Musculoskelet Disord 2007; 8: 37.

[34] Vallbracht I, Rieber J, Oppermann M, Förger F, Siebert $U$, Helmke K. Diagnostic and clinical value of anticyclic citrullinated peptide antibodies compared with rheumatoid factor isotypes in rheumatoid arthritis. Ann Rheum Dis 2004; 63(9): 1079-1084.

[35] Sihvonen S, Korpela M, Mustila A, Mustonen J. The predictive value of rheumatoid factor isotypes, anticyclic citrullinated peptide antibodies, and antineutrophil cytoplasmic antibodies for mortality in patients with rheumatoid arthritis. J Rheumatol 2005; 32(11): 2089-2094.

[36] Kastbom A, Strandberg G, Lindroos A, Skogh T. Anti-CCP antibody test predicts the disease course during 3 years in early rheumatoid arthritis (the Swedish TIRA project). Ann Rheum Dis 2004; 63(9): 1085-1089.

[37] Kroot EJ, de Jong BA, van Leeuwen MA, Swinkels $H$, van den Hoogen FH, van't Hof M, van de Putte LB, van Rijswijk $\mathrm{MH}$, van Venrooij WJ, van Riel PL. The prognostic value of anti-cyclic citrullinated peptide antibody in patients with recent-onset rheumatoid arthritis. Arthritis Rheum 2000; 43(8): 1831-1835.

[38] Heidari B, Firouzjahi A, Heidari P, Hajian K. The prevalence and diagnostic performance of anti-cyclic citrullinated peptide antibody in rheumatoid arthritis: the predictive and discriminative ability of serum antibody level in recognizing rheumatoid arthritis". Ann Saudi Med 2009; 29(6): 467-470.

[39] Linn-Rasker SP, van der Helm-van Mil AH, van Gaalen FA, Kloppenburg M, de Vries RR, le Cessie S, Breedveld FC, Toes RE, Huizinga TW. Smoking is a risk factor for anti-CCP antibodies only in rheumatoid arthritis patients who carry HLA-DRB1 shared epitope alleles. Ann Rheum Dis 2006; 65(3): 366-371.

[40] Alsalahy MM, Nasser HS, Hashem MM, Elsayed SNM. Effect of tobacco smoking on tissue protein citrullination and disease progression in patients with rheumatoid arthritis. Saudi Pharm J 2010; 18(2): 75-80.

[41] Chang K, Yang SM, Kim SH, Han KH, Park SJ, Shan JI:Smoking and rheumatoid arthritis. Int J Mol Sci 2014; 15(12): 2227922295.

[42] Sokka T, Kautiainen H, Pincus T, Toloza S, da Rocha Castelar Pinheiro G, Lazovskis J, Hetland ML, Peets T, Immonen K, Maillefert JF, Drosos AA, Alten R, Pohl C, Rojkovich B, Bresnihan B, Minnock P, Cazzato M, Bombardieri S, Rexhepi S, Rexhepi M, Andersone D, Stropuviene S, Huisman M, Sierakowski S, Karateev D, Skakic V, Naranjo A, Baecklund E, Henrohn D, Gogus F, Badsha H, Mofti A, Taylor P, McClinton C, Yazici Y. Disparities in rheumatoid arthritis disease activity according to gross domestic 
product in 25 countries in the QUEST-RA database. Ann Rheum Dis 2009; 68(11): 1666-1672.

[43] Serdaroğlu M, Cakirbay H, Değer O, Cengiz S, Kul S. The association of anti-CCP antibodies with disease activity in rheumatoid arthritis. Rheumatol Int 2008; 28(10): 965970.

[44] Forslind K, AhImén M, Eberhardt K, Hafström I, Svensson B; BARFOT Study Group. Prediction of radiological outcome in early rheumatoid arthritis in clinical practice: role of antibodies to citrullinated peptides (anti-CCP). Ann Rheum Dis 2004; 63(9): 1090-1095.

[45] Silman S, Oliver J. Epidemiology of the rheumatic diseases. In: ABC of Rheumatology. $4^{\text {th }}$ edn. Adebajo A, ed. Oxford, UK: Wiley-Blackwell Pub Ltd, 2010. 167-170.

[46] Almoallim HM, Alharbi LA. Rheumatoid arthritis in Saudi Arabia. Saudi Med J 2014; 35(12): 1442-1454.

[47] Al-Dalaan A, Al Ballaa S, Bahabri S, Biyari T, Al Sukait M, Mousa M. The prevalence of rheumatoid arthritis in the Qassim region of Saudi Arabia. Ann Saudi Med 1998; 18(5): 396-397.

[48] Alrogy A, Dirar A, Alrogy W, Fakhoury H, Hajeer A. Association of human leukocyte antigen DRB1 with anti-cyclic citrullinated peptide autoantibodies in Saudi patients with rheumatoid arthritis. Ann Saudi Med 2017; 37(1): 38-41. 

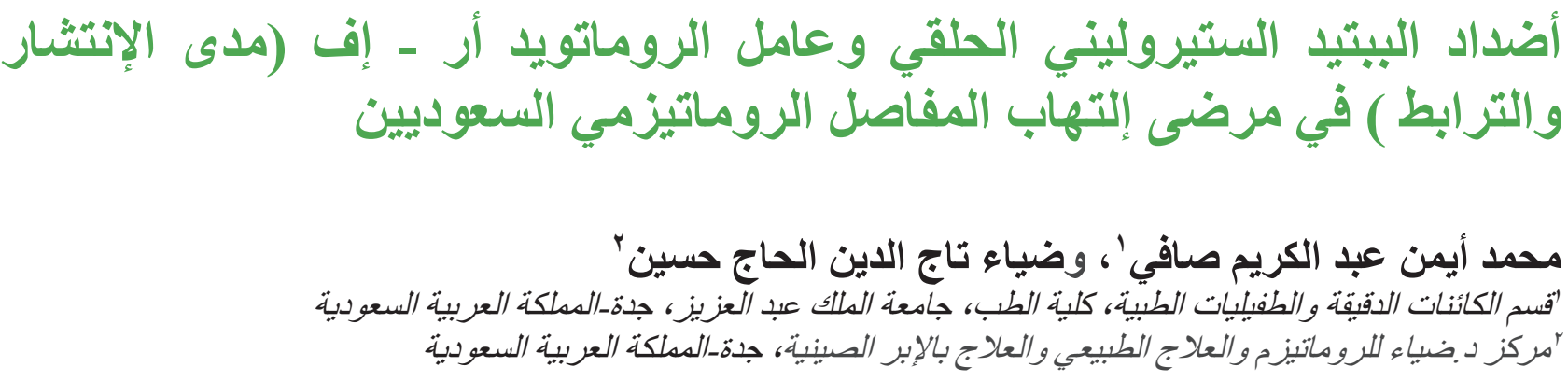

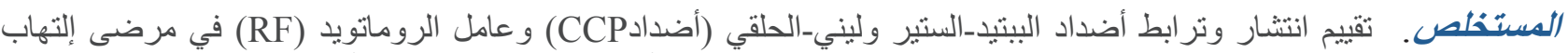

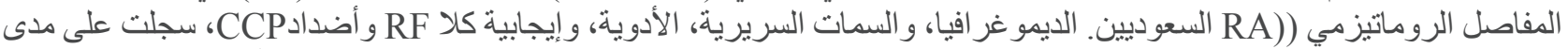

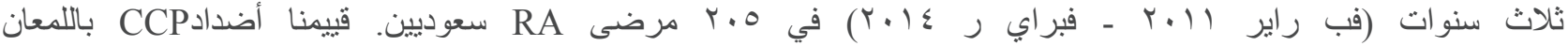

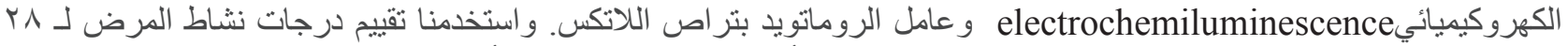

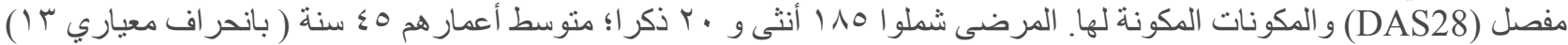

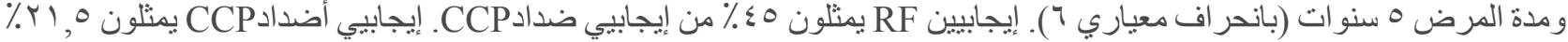

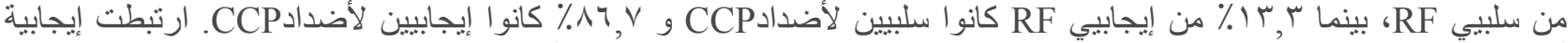

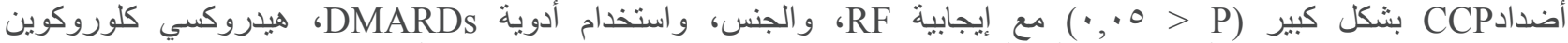

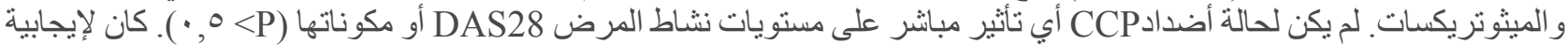

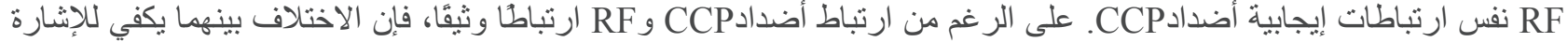

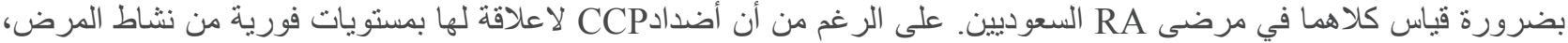

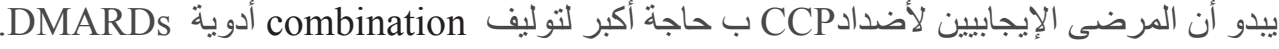

